\title{
PELATIHAN PEMANFAATAN GOOGLE CLASSROOM UNTUK MENINGKATKAN KEMAMPUAN GURU DALAM PEMBELAJARAN DARING
}

\author{
Elin Yuliani \\ SMA Negeri 7 Tasikmalaya, Jalan Air Tanjung No.25, Kawalu, Tasikmalaya, Indonesia \\ Email: elinyuliani@gmail.com
}

\begin{abstract}
Currently, the whole world is trying to deal with COVID-19 which affects all of life aspects including education. The current pandemic conditions lead the online learning to be carried out; while teachers, in general, have not mastered online learning applications yet. Therefore, training on the use of Google Classroom is held to improve the teachers' ability to teach online at SMAN 7 Tasikmalaya. This research is a School Action Research (PTS) involving 42 teachers in SMAN 7 Tasikmalaya and using the instrument of questionnaire. Based on the questionnaire result, it is found that the first cycle has not been met yet because it has not reached the success criteria. It indicates that of all 42 people, only 9 people with a large percentage of only $21 \%$ of participants get score 5 , and the remaining $79 \%$ of participants have not received a score of 5 yet. The average of cycle 1 is 2.67 . Furthermore, based on the observations, it is found that the first cycle has a value of 1 and this is not in accordance with the success criteria. Then, the second cycle has been fulfilled because the success criteria has been achieved, namely, of all 42 people, 35 people with a large percentage of $83 \%$ of participants who got a score of 5 and the remaining $17 \%$ of participants have not obtained a value of 5 . This is in accordance with the criteria for the success of the action.
\end{abstract}

Keywords: Google Classroom, Online Learning.

\begin{abstract}
ABSTRAK
Saat ini, seluruh dunia sedang berupaya untuk menghadapi COVID-19 yang mempengaruhi semua aspek dalam kehidupan termasuk dalam pendidikan. Kondisi pandemi saat ini membuat pembelajaran harus dilakukan secara daring sedangkan guru pada umumnya belum menguasai aplikasi-aplikasi pembelajaran daring. Oleh sebab itu diadakan pelatihan penggunaan Google Classroom untuk meningkatkan kemampuan guru dalam mengajar daring di SMAN 7 Tasikmalaya. Penelitian ini merupakan Penelitian Tindakan Sekolah (PTS). Subjek penelitian ini adalah 42 orang guru SMAN 7 Tasikmalaya. Instrumen penelitian ini adalah angket. Berdasarkan hasil pengisian angket diperoleh bahwa siklus I belum terpenuhi karena belum mencapai kriteria keberhasilan yaitu hanya 9 dari 42 orang dengan besar prosentase hanya $21 \%$ peserta yang memperoleh nilai 5 dan sisanya sebanyak $79 \%$ peserta belum memperoleh nilai 5 . Rerata siklus 1 sebesar 2,67. Selanjutnya berdasarkan hasil observasi diperoleh bahwa siklus I nilainya sebesar 1 dan hal ini belum sesuai dengan kriteria keberhasilan. Pada siklus II telah terpenuhi karena telah mencapai kriteria keberhasilan yaitu 35 orang dari 42 orang dengan besar prosentase $83 \%$ peserta yang memperoleh nilai 5 dan sisanya sebanyak $17 \%$ peserta belum memperoleh nilai 5 . Selanjutnya berdasarkan hasil observasi diperoleh bahwa siklus ॥ nilainya sebesar 3 dan hal ini telah sesuai dengan kriteria keberhasilan tindakan.
\end{abstract}

Kata Kunci: Google Classroom, Pembelajaran Daring.

Cara sitasi: Yuliani, E. (2021). Pelatihan pemanfaatan google classroom untuk meningkatkan kemampuan guru dalam pembelajaran daring. J-KIP (Jurnal Keguruan dan IImu Pendidikan), 2 (2), 91-96. 


\section{PENDAHULUAN}

Saat ini, seluruh dunia sedang berupaya untuk menghadapi COVID-19 yang mempengaruhi semua aspek dalam kehidupan kita. Pada awalnya, pengaruh COVID-19 hanya dirasakan oleh sektor ekonomi yang mengalami penurunan drastis. Tetapi, lama kelamaan pengaruh COVID-19 juga dirasakan oleh berbagai sektor termasuk pendidikan. Sejak pemerintah mengumumkan kasus pertama COVID-19 di Indonesia pada tanggal 2 Maret 2020, pemerintah mengimbau masyarakat untuk mengurangi aktivitas yang dilakukan diluar rumah demi menekan angka penyebaran COVID19 di Indonesia. Kebijakan pemerintah yang mewajibkan masyarakat untuk melakukan physical distancing menyebabkan para pelajar harus melakukan pembelajaran di rumah secara online. Sesuai data dari UNESCO, sampai saat ini sudah ada 39 negara yang menerapkan pembelajaran online dengan total jumlah pelajar yang terpengaruh mencapai 421.388 .462 anak. Di Indonesia, Kemendikbud bekerja sama dengan Kelas Pintar, Sekolahmu, Zenius, Ruang Guru,Quipper, Google Indonesia dan Microsoft yang dapat diakses untuk membantu para siswa dalam menjalani pembelajaran daring.

Bagi kota-kota besar, hal ini tentunya memberikan manfaat bagi para siswa, dan aktivitas belajar mengajar secara online pun terbilang berjalan dengan lancar. Tetapi tidak dengan sekolahsekolah yang berada di pedesaan atau wilayah pelosok. Tidak semua orang memiliki alat komunikasi dan jaringan internet yang memadai untuk bersekolah secara online. Alhasil, pembelajaran di wilayah pedesaan dan pelosok terhambat dan bahkan siswa-siswa disana tidak mendapatkan pengajaran sama sekali selama kebijakan ini berlangsung seakanakan sekolah diliburkan dan menyebabkan siswa terpaksa belajar mandiri. Selain itu, tidak semua guru di sekolah akrab dengan teknologi informasi.

Setiap mancanegara merespon terhadap Corona dengan menyediakan platform pendidikan resmi dari pemerintah masing-masing. Rumah Belajar merupakan platform yang menyediakan konten pembelajaran, sistem manajemen pembelajaran untuk kelas online, dan sumber daya lainnya. Sedangkan SPADA merupakan platform pembelajaran elektronik gratis untuk mahasiswa perguruan tinggi (Sarjana dan Diploma). Selain platform yang disediakan secara resmi oleh pemerintah, siswa dapat berinteraksi dengan guru menggunakan beberapa aplikasi seperti google classroom, video converence, telepon atau live chat, zoom maupun melalui whatsapp group. Dengan demikian fokus dari penelitian ini adalah untuk meningkatkan kemampuan guru dalam mengajar daring dengan memanfaatkan google classroom. Dengan demikian tujuan dari penelitian ini adalah untuk mengatahui bagaimanakah pengaruh pelatihan penggunaan Google Classroom terhadap peningkatkan kemampuan guru dalam mengajar daring di SMAN 7 Tasikmalaya?.

\section{METODE PENELITIAN}

Penelitian ini merupakan Penelitian Tindakan Sekolah dengan banyaknya subjek penelitian sebanyak 42 orang sesuai dengan jumlah guru pada tahun 2020 yang ada di SMA Negeri 7 Tasikmalaya. Siklus I dilaksanakan pada tanggal 20 April 2020 dengan alokasi waktu (2x40) dan Siklus II dilaksanakan pada tanggal 27 April 2020 dengan alokasi waktu (2x40). Siklus I dan II melalui tahap perencanaan, pelaksanaan, pengamatan dan refleksi. Instrumen yang digunakan berupa angket.

\section{HASIL DAN PEMBAHASAN}

Berdasarkan hasil pengisian angket diperoleh bahwa siklus I belum terpenuhi karena belum mencapai kriteria keberhasilan yaitu hanya 9 dari 42 orang dengan besar prosentase hanya $21 \%$ peserta yang memperoleh nilai 5 dan sisanya sebanyak $79 \%$ peserta belum memperoleh nilai 5 . Hasil penelitian ini disajikan pada Gambar 1. 


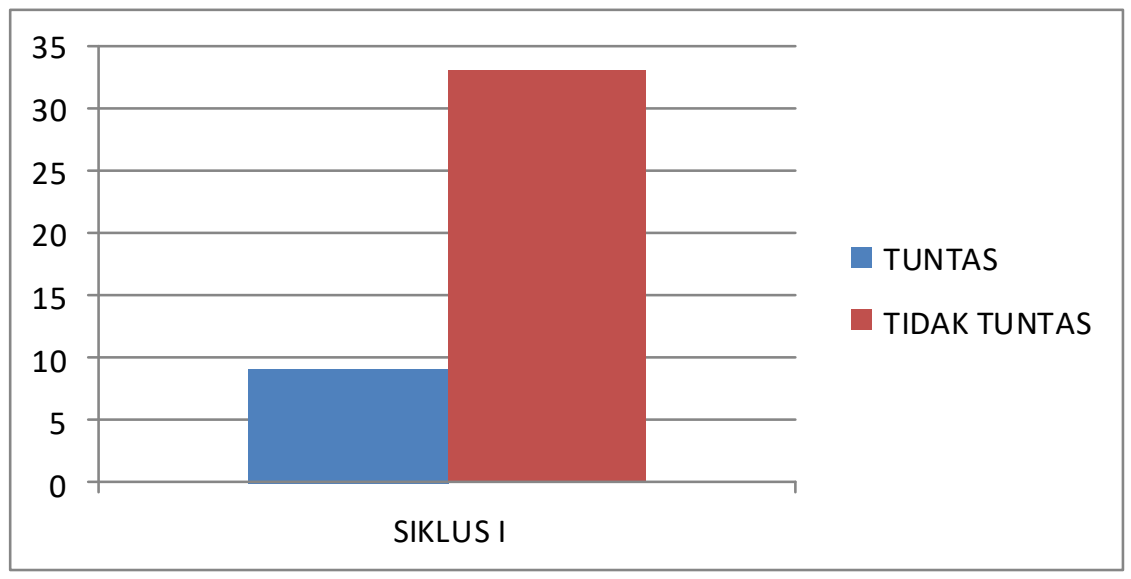

Gambar 1. Hasil Pengisian Angket Siklus I

Selanjutnya berdasarkan hasil observasi diperoleh bahwa nilainya sebesar 1 dan hal ini belum sesuai dengan kriteria keberhasilan tindakan yang diperoleh dari hasil pengisian angket yang tercantum pada Tabel 4.

Tabel 1. Hasil Penilaian Observer

\begin{tabular}{clcc}
\hline No & \multicolumn{1}{c}{ Aspek Penilaian } & Ya & Tidak \\
\hline 1 & $\begin{array}{l}\text { Lebih dari } 50 \% \text { peserta menyimak pemaparan materi mengenai } \\
\text { Google Classroom }\end{array}$ & $\mathrm{V}$ \\
2 & $\begin{array}{l}\text { Lebih dari } 50 \% \text { peserta aktif bertanya mengenai materi Google } \\
\text { Classroom } \\
\text { Lebih dari 25\% peserta bersedia mengeshare screen tampilan } \\
\text { Google Classroom }\end{array}$ & $\mathrm{V}$ \\
\end{tabular}

Diperoleh hasil refleksi sebagai berikut:

a. Peserta kurang kooperatif saat diminta untuk share screen tampilan Google Classroom.

b. Saat tanya jawab peserta kurang aktif.

Semua kekurangan tersebut akan di perbaiki di siklus II.

Berdasarkan hasil pengisian angket diperoleh bahwa siklus II telah terpenuhi karena telah mencapai kriteria keberhasilan yaitu 35 orang dari 42 orang dengan besar prosentase $83 \%$ peserta yang memperoleh nilai 5 dan sisanya sebanyak $17 \%$ peserta belum memperoleh nilai 5 . Hasil penelitian ini disajikan pada Gambar 2.

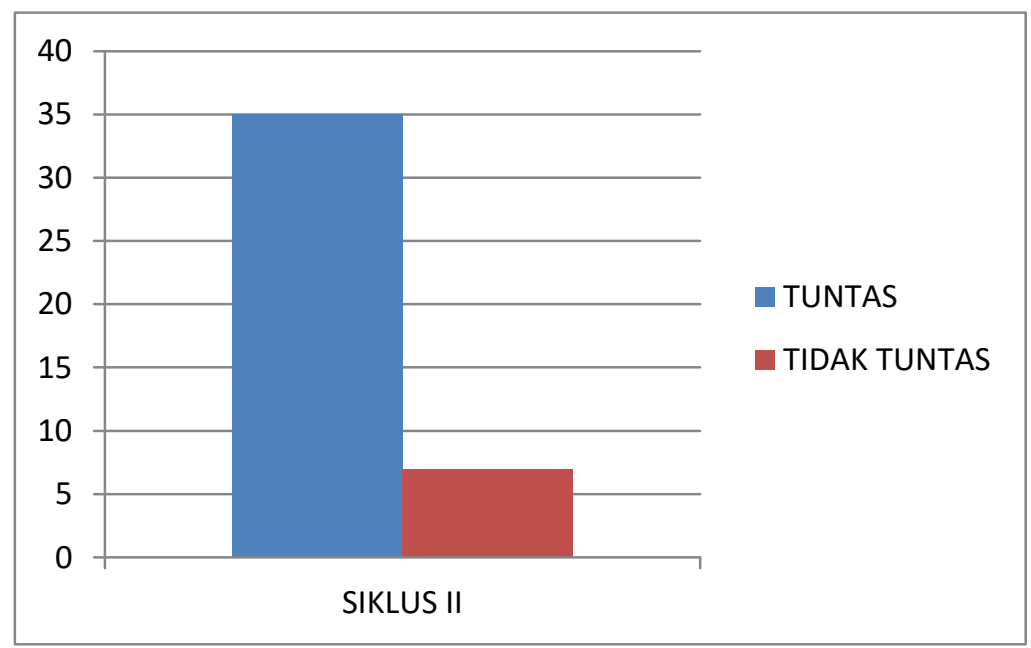

Gambar 2. Hasil Pengisian Angket Siklus II 
Selanjutnya berdasarkan hasil observasi diperoleh bahwa nilainya sebesar 3 dan hal ini telah sesuai dengan kriteria keberhasilan tindakan yang diperoleh dari hasil pengisian angket yang tercantum pada Tabel 2.

Tabel 2. Hasil Penilaian Observer

\begin{tabular}{clll}
\hline No & \multicolumn{1}{c}{ Aspek Penilaian } & Ya & Tidak \\
\hline 1 & $\begin{array}{l}\text { Lebih dari } 50 \% \text { peserta menyimak pemaparan materi mengenai } \\
\text { Google Classroom } \\
\text { Lebih dari } 50 \% \text { peserta aktif bertanya mengenai materi Google } \\
\text { Classroom }\end{array}$ & $\mathrm{V}$ & \\
& $\begin{array}{l}\text { Lebih dari 25\% peserta bersedia mengeshare screen tampilan } \\
\text { Google Classroom }\end{array}$ & $\mathrm{V}$ \\
\hline
\end{tabular}

Selama pelaksanaan siklus II tampak ada perubahan pada kegiatan yaitu guru-guru lebih aktif mengikuti kegiatan yang terlihat dari peserta kooperatif saat diminta untuk share screen tampilan Google Classroom dan juga saat tanya jawab peserta lebih aktif.

Pelaksanaan penelitian tindakan kelas dilakukan sebanyak 2 siklus dengan rangkuman hasil sebagai berikut:

Tabel 3. Rincian Hasil Tiap Siklus

\begin{tabular}{ccc} 
& \multicolumn{2}{c}{ Tabel 3. Rincian Hasil Tiap Siklus } \\
\cline { 2 - 3 } & $\begin{array}{c}\text { Hasil Pengisian Angket } \\
\text { Siklus I }\end{array}$ & $\begin{array}{c}\text { Hasil Pengisian Angket } \\
\text { Siklus II }\end{array}$ \\
\hline $\begin{array}{c}\text { Nilai rerata } \\
\begin{array}{c}\text { Persentase } \\
\text { keberhasilan }\end{array}\end{array}$ & 2,67 & 4,55 \\
Keputusan & $21 \%$ & $83 \%$ \\
\hline
\end{tabular}

Keputusan berdasarkan kriteria keberhasilan:

a. Siklus I dikatakan berhasil apabila 50\% peserta mencapai nilai 5 .

b. Siklus II dikatakan berhasil apabila $60 \%$ peserta mencapai nilai 5 .

Selanjutnya untuk penilaian observer diperoleh hasil sebagai berikut:

Tabel 4. Rincian Hasil Tiap Siklus

\begin{tabular}{ccc} 
& $\begin{array}{c}\text { Hasil Pengisian Angket } \\
\text { Observer Siklus I }\end{array}$ & $\begin{array}{c}\text { Hasil Pengisian Angket } \\
\text { Observer Siklus II }\end{array}$ \\
\hline Nilai & 1 & 3 \\
Keputusan & Belum berhasil & Telah berhasil \\
\hline
\end{tabular}

a. Siklus I dikatakan berhasil apabila penilaian observer terhadap peserta mencapai nilai 2.

b. Siklus II dikatakan berhasil apabila penilaian observer terhadap peserta mencapai nilai 3.

Berdasarkan hasil penelitian maka diketahui bahwa pelatihan penggunaan Google Classroom terdapat peningkatkan kemampuan guru dalam mengajar daring di SMAN 7 Tasikmalaya.

\section{KESIMPULAN}

Berdasarkan hasil pengisian angket diperoleh bahwa siklus I belum terpenuhi karena belum mencapai kriteria keberhasilan yaitu hanya 9 dari 42 orang dengan besar prosentase hanya $21 \%$ peserta yang memperoleh nilai 5 dan sisanya sebanyak $79 \%$ peserta belum memperoleh nilai 5 . Rerata siklus 1 sebesar 2,67. Selanjutnya berdasarkan hasil observasi diperoleh bahwa siklus I nilainya sebesar 1 dan hal ini belum sesuai dengan kriteria keberhasilan. Berdasarkan hasil pengisian angket diperoleh bahwa siklus II telah terpenuhi karena telah mencapai kriteria keberhasilan yaitu 35 orang dari 42 orang dengan besar prosentase $83 \%$ peserta yang memperoleh 
nilai 5 dan sisanya sebanyak $17 \%$ peserta belum memperoleh nilai 5 . Selanjutnya berdasarkan hasil observasi diperoleh bahwa siklus II nilainya sebesar 3 dan hal ini telah sesuai dengan kriteria keberhasilan tindakan.

\section{REKOMENDASI}

Sebaiknya pelatihan juga mencakup materi penggunaan aplikasi pembelajaran daring selain google classroom sehingga guru dapat menguasai berbagai macam aplikasi yang dapat digunakan pada pembelajaran daring.

\section{UCAPAN TERIMA KASIH}

Penulis mengucapkan terima kasih kepada para guru SMAN 7 Tasikmalaya yang telah bersedia menjadi subjek penelitian ini.

\section{DAFTAR PUSTAKA}

Maharani, N., \& Kartini, K. S. (2019). Penggunaan google classroom sebagai pengembangan kelas virtual dalam keterampilan pemecahan masalah topik kinematika pada mahasiswa jurusan sistem computer. PENDIPA J. Sci. Educ., 3 (3), 167-173, doi: 10.33369/pendipa.

Nurhijrah \& Suryana, S. (2020). Pengembangan kompetensi guru menggunakan aplikasi google classroom pada masa pandemic covid-19. Jurnal MediaTIK : Jurnal Media Pendidikan Teknik Informatika dan Komputer, 2 (2).

Sun, A., \& Chen, X. (2016). Online education and its effective practice: a research review. J. Inf. Technol. Educ. Res., 15 (2016), 157-190, doi: 10.28945/3502.

Sabran., \& Sabara, E. (2019). Keefektifan google classroom sebagai media pembelajaran, Pros. Semin. Nas. Lemb. Penelit. Univ. NEGERI Makasar.

Soni et al., (2018). Optimalisasi pemanfaatan google classroom sebagai media pembelajaran di smk negeri 1 bangkinang. J. Pengabdi. Untuk Mu NegeRI. 
